\title{
Indications of associative nitrogen fixation in eastern gamagrass
}

\author{
JOHN J. BREJDA, ROBERT J. KREMER, AND JAMES R. BROWN
}

\begin{abstract}
Authors are graduate research assistant, Department of Agronomy, 279 Plant Science, University of Nebraska, Lincoln 68583; microbiologist, USDA-ARS, Cropping Systems and Water Quality Unit, 144 Mumford Hall, University of Missouri, Columbia 65211; and professor, School of Natural Resources, 144 Mumford Hall, University of Missouri, Columbia 65211.
\end{abstract}

\begin{abstract}
Associative nitrogen-fixation is one mechanism by which plants can meet a portion of their nitrogen $(N)$ needs in $N$ deficient environments. Eastern gamagrass [Tripsacum dactyloides (L.) L.] grows under conditions conducive for associative $\mathbf{N}$-fixation. Our objective was to evaluate eastern gamagrass roots for nitrogenase activity and associated $\mathrm{N}$-fixing bacteria, and compare its nitrogenase activity to switchgrass (Panicum virgatum $\mathrm{L}$.). Soil and root samples were collected from unfertilized stands of "PMK-24" eastern gamagrass at 3 locations in northern Missouri and nitrogenase activity measured using the acetylene reduction method. Eastern gamagrass roots supported greater nitrogenase activity when colonized by indigenous bacteria, compared to roots inoculated with Klebsiella pneumoniae or surface sterilized. Eastern gamagrass roots colonized by indigenous bacteria had 17-46 fold greater nitrogenase activity than switchgrass roots. Bacterial composition on eastern gamagrass roots was dominated by fluorescent pseudomonads and Pseudomonas cepacia, with lower populations of other bacteria. Bacterial composition from incubation tubes showing nitrogenase activity was similar to that found on the roots, except that the diazotrophic bacterium $A$ zospirillum braziliense was isolated from 1 of 3 sites. The potential for associative $N$ fixation with eastern gamagrass warrants further study and in situ measurement to quantify rates of $\mathbf{N}$ fixation.
\end{abstract}

Key Words: Nonsymbiotic nitrogen-fixation, diazotrophic bacteria, Tripsacum dactyloides (L.) L.

In ecosystems where legumes are sparse or absent, associative nitrogen-fixation, or nitrogen (N) fixation by free-living diazotrophic bacteria associated with the roots of nonleguminous plants, can be a mechanism for meeting part of the $\mathrm{N}$ requirements of plants. Associative $\mathrm{N}$-fixation has been reported in both $\mathrm{C}_{3}$ and $\mathrm{C}_{4}$ grasses, but $\mathrm{C}_{4}$ grasses may be better candidates for associative $\mathrm{N}$-fixation because of their greater photosynthetic efficiency (Neyra and Dobereiner 1977). Associative N-fixation appears to be more common in tropical and subtropical environments, but low rates of associative $\mathrm{N}$-fixation have been reported for several $\mathrm{C}_{4}$ species, including corn (Zea mays L.) (Barber et al. 1976, Albrecht et al. 1981); sorghum [Sorghum bicolor (L.) Moench] (Pedersen et al. 1978, Klucas and Pedersen 1980); and switchgrass (Panicum virgatum L.) (Tjepkema 1975, Tjepkema and Burris 1976, Morris

\footnotetext{
Joint contribution of the USDA-ARS and the University of Missouri Agr. Exp. Joint contribution of the USDA-ARS and the University of Missouri Agr. Exp.
Sta. as Journal Article 11,983. The authors thank Dan Shepherd of Shepherd Farms; Jimmy Henry, Soil Conservation Service Elsberry Plant Materials Center; and John Poehlman, University of Missouri Agronomy Research Center, for making available eastern gamagrass stands, and the Missouri Department of Conservation for financial support.

Manuscript accepted 31 Dec. 1993.
}

et al. 1985) growing in temperate climates. Conditions favorable for associative $\mathrm{N}$-fixation include low availability of combined soil $\mathrm{N}$, high soil moisture, a readily available energy source, and low $\mathrm{O}_{2}$ concentrations in the rhizosphere (Klucas 1991).

Eastern gamagrass [Tripsacum dactyloides $\left(\mathrm{L}\right.$.) $\mathrm{L}$.] is a native $\mathrm{C}_{4}$ species that grows from Massachusetts west to Michigan, Iowa, and Nebraska, and south to Florida, Texas, and the West Indies (Hitchcock and Chase 1971). Eastern gamagrass is commonly found in low lying areas, near stream banks, and in other areas where soil moisture is high. Its $\mathrm{C}_{4}$ photosynthetic pathway, temperate through tropical distribution, and preference for mesic sites suggest that eastern gamagrass could potentially support associative $\mathrm{N}$-fixation. The objective of this research was to evaluate eastern gamagrass roots for nitrogenase activity and associated $\mathrm{N}$-fixing bacteria, and compare its nitrogenase activity with switchgrass.

\section{Materials and Methods}

Soil and root samples were collected from unfertilized seeded stands of "PMK-24" eastern gamagrass at 3 locations in northern Missouri. The first site was a 4-year old stand at the University of Missouri Agronomy Research Center near Columbia, Mo. Soil at the Columbia site was a Mexico silt loam (fine, montmorillonitic, mesic Udollic Ochraqualf). The second site was a 3-year old stand at the USDA-SCS Elsberry Plant Materials Center near Elsberry, Mo. Soil at the Elsberry site was a Chequest silty clay loam (fine, montmorillonitic, mesic noncalcareous Typic Haplaquoll). The third site was a 6-year old stand at Shepherd Farms near Clifton Hill, Mo., where the soil was a Piopolis silty clay loam (fine-silty, mixed, acid, mesic Typic Fluvaquent).

\section{Nitrogenase Activity}

On 22 May 1992 soil and root samples were collected under the crowns of 4 eastern gamagrass plants chosen at random at each site. Samples were collected to a depth of $15 \mathrm{~cm}$ using a $2.5-\mathrm{cm}$ diameter soil probe. The roots from each plant were kept separate and washed free of soil with distilled water. Each root sample was subdivided into 3 subsamples. One of the subsamples was left untreated for evaluation of the indigenous bacteria. The other 2 subsamples were surface sterilized by immersion in $10 \% \mathrm{H}_{2} \mathrm{O}_{2}$ for 1 minute. One of the surface sterilized subsamples were reinoculated with the known $\mathrm{N}$-fixing bacterium Klebsiella pneumoniae to serve as a $\mathrm{N}$-fixing standard.

A 1-cm root segment from each treatment was placed in a $15-\mathrm{ml}$ Hungate tube containing $5 \mathrm{ml}$ of $\mathrm{N}$-free semisolid agar used for detecting N-fixing activity in pseudomonads (Lifshitz et al. 1986). Three tubes were prepared for each plant-treatment combination. 
The tubes were fitted with rubber septate and incubated in the dark for 1 week at $35^{\circ} \mathrm{C}$. Nitrogenase activity was evaluated by measuring the quantity of acetylene reduced to ethylene. Following incubation, $2 \mathrm{ml}$ of air were removed from each tube and replaced with $2 \mathrm{ml}$ of acetylene generated from $\mathrm{CaC}_{2}$, with additional incubation for 1 hour. Following incubation, the gas in each tube was mixed and $0.5 \mathrm{ml}$ injected into a gas chromatograph fitted with a stainless steel column packed with Porapak R. Ethylene was quantified with a hydrogen-oxygen flame ionization detector sensititive to $<1$ nmol. The carrier gas was $\mathrm{N}_{2}$ at $2 \mathrm{ml}$ minute ${ }^{-1}$.

On 22 June 1992 the experiment was repeated by sampling 4 different eastern gamagrass plants chosen at random at the same sites. In addition, 2 switchgrass plants were sampled from adjacent seeded stands with similar soils at each site. At Columbia and Clifton Hill, switchgrass samples were collected from 10- and 6-year old stands of "Blackwell," and at Elsberry samples were collected from a 15-year old stand of "Cave-in-Rock." The soilroot samples were treated as described previously.

\section{Bacterial Isolation and Identification}

Bacteria were isolated directly from eastern gamagrass roots collected 22 June 1992. Roots were washed in distilled water and suspended in phosphate-buffered saline solution ( $\mathrm{pH} 7.0$ ) plus $0.5 \%$ surfactant, macerated, and 10 -fold dilutions of macerates were placed on nutrient agar. After incubation at $27^{\circ} \mathrm{C}$ for 3 days, colony forming units (cfu) were counted, representative colony types were isolated on fresh nutrient agar, and each was identified using the API Rapid NFT diagnostic kit (BoiMerieux Vitek Inc., Hazelwood, Mo.). The kit consists of a set of 20 different substrates that are inoculated with a suspension of the bacterial isolate. After a 48-hour incubation, reactions in the substrates are scored positive or negative and used to determine a numerical code, which is matched to profiles in the identification codebook accompanying the kit. Identification of the bacteria was verified with gas chromatography-fatty acid methyl ester analysis (Sasser 1990). Cultures from tubes showing significant nitrogenase activity were streaked onto nutrient agar plates and bacterial species were isolated using standard plating techniques. Relative species composition of bacteria in active tubes at each site was determined by dividing the number of tubes containing each bacterial species by the total number of tubes showing activity and multiplying by 100 . Bacterial isolates were identified with the API diagnostic kit.

Data were analyzed separately from each experiment using analysis of variance for a completely randomized design. In the first experiment, the 4 eastern gamagrass plants sampled at each site were used as replications. Sites were considered a random effect and data were analyzed in a split-plot design with sites as the whole-plot effect and bacterial treatments as the subplot. In the second experiment, the 4 eastern gamagrass and 2 switchgrass plants sampled at each site were considered replicates in a completely randomized design with unequal replication (Gomez and Gomez 1984). Sites were considered a random effect and variation was partitioned in a split-plot design with sites as whole plots and a factorial combination of grass species and bacterial treatments in subplots.

\section{Results and Discussion}

\section{Nitrogenase Activity}

Eastern gamagrass roots collected 22 May showed greater nitrogenase activity when colonized by indigenous bacteria compared to roots inoculated with Klebsiella pneumoniae or surface sterilized (Table 1). However, the response varied between locations, resulting in a significant location by bacterial treatment interaction. At Clifton Hill, roots colonized by indigenous bacteria had 5.0-8.3 fold greater nitrogenase activity than roots inoculated
Table 1. Nitrogenase activity by indigenous bacteria associated with eastern gamagrass roots collected 22 May 1992 from 3 north Missouri locations, or surface sterilized roots reinoculated with Klebsiella pneumoniae.

\begin{tabular}{lccc}
\hline \hline & & & Clifton \\
Treatment & Columbia & Elsberry & Hill \\
\hline & $---\left(\mathrm{nmol} \mathrm{C}_{2} \mathrm{H}_{4} \mathrm{ml}^{-1}\right.$ & hour $\left.^{-1}\right)$ & $\ldots-$. \\
Indigenous bacteria & 5.2 & 10.0 & 21.7 \\
Klebsiella pneumoniae & 0.6 & 9.3 & 4.3 \\
Surface sterilized & 0.3 & 0.5 & 2.6 \\
$\mathrm{P}>\mathrm{F}$ & $\mathrm{NS}$ & 0.01 & 0.01 \\
$\mathrm{CV}(\%)$ & 176 & 51 & 66 \\
\hline
\end{tabular}

with K. pneumoniae or surface sterilized. At Elsberry, roots colonized by indigenous bacteria or inoculated with $K$. pneumoniae had 18-20 fold greater activity than surface sterilized roots, with no difference between the indigenous bacteria and $K$. pneumoniae treatments. Nitrogenase activity by indigenous bacteria was also greater with root samples from Columbia, but large variances (CV=176\%) prevented detection of significant differences.

When the experiment was repeated on 22 June, eastern gamagrass roots from all 3 locations colonized by indigenous bacteria showed significantly greater nitrogenase activity than roots inoculated with $K$. pneumoniae or surface sterilized (Table 2). Differences in nitrogenase activity between the 3 locations did not differ significantly. Location by bacterial treatment or grass species interactions were also not significant. Eastern gamagrass roots inoculated with $K$. pneumoniae showed low levels of activity (4.1-28.5 nmol $\mathrm{C}_{2} \mathrm{H}_{4} \mathrm{ml}^{-1}$ hour $\left.{ }^{-1}\right)$ compared to roots colonize by indigenous bacteria (Table 2).

Eastern gamagrass roots had $17-46$ fold greater nitrogenase activity compared to switchgrass roots when each was colonized by indigenous bacteria (Table 2). When analyzed over all 3 locations, eastern gamagrass roots had significantly greater $(P<0.01)$ nitrogenase activity than switchgrass roots, but when analyzed separately for each location, differences between grass species were significant at only the Columbia and Elsberry locations. Switchgrass roots inoculated with $K$. pneumoniae did not show significant nitrogenase activity.

\section{Bacterial Species Composition}

Bacterial species isolated from eastern gamagrass roots collected on 22 June were similar for Columbia and Elsberry (Table 3). The bacterial population was dominated by fluorescent pseudomonads and Pseudomonas cepacia, with lower populations of Xanthomonas maltophilia, Rhodococcus spp., Agrobactrium spp., and Bacillus spp. Roots collected at Clifton Hill had significantly lower populations of fluorescent pseudomonads, $P$. cepacia, Rhodococcus spp., and Agrobacterium spp. than Columbia or Elsberry.

Some Pseudomonas spp. are capable of nitrogenase activity (Barraquio et al. 1983, Lifshitz et al. 1986), but rates of activity can be small and highly variable. $P$. fluorescens and $P$. putida, both fluorescent pseudomonads isolated from the roots of eastern gamagrass, are commonly isolated from plant rhizospheres and have demonstrated phytopathogenic activity. $P$. cepacia, a nonfluorescent pseudomonad, has been isolated from the caryopses of eastern gamagrass seeds collected from several locations in Illinois (Anderson and Liberta 1986, Jayaswal et al. 1990), and its presence indicates the possibility of seedborne bacteria establishment in the rhizosphere. P. cepacia has also demonstrated to be phytopathogenic (Jayaswal et al. 1990).

Bacteria isolated from cultures in tubes showing nitrogenase activity were similar in species compositions as those found on the roots, with 2 exceptions (Table 4). The diazotrophic bacterium 
Table 2. Nitrogenase activity by indigenous bacteria associated with roots of eastern gamagrass and switchgrass collected 22 June 1992 from 3 north Missouri locations, or surface sterilized roots reinoculated with Klebsiella pneumoniae.

\begin{tabular}{|c|c|c|c|c|c|c|}
\hline \multirow[b]{2}{*}{ Treatment } & \multicolumn{2}{|c|}{ Columbia } & \multicolumn{2}{|c|}{ Elsberry } & \multicolumn{2}{|c|}{ Clifton Hill } \\
\hline & $\begin{array}{c}\text { Eastern } \\
\text { gamagrass }\end{array}$ & Switchgrass & $\begin{array}{c}\text { Eastern } \\
\text { gamagrass }\end{array}$ & Switchgrass & $\begin{array}{c}\text { Eastern } \\
\text { gamagrass }\end{array}$ & Switchgrass \\
\hline & \multicolumn{6}{|c|}{ 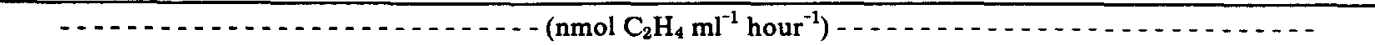 } \\
\hline Indigenous bacteria & 306.9 & 17.5 & 401.5 & 8.7 & 679.5 & 17.1 \\
\hline Klebsiella pneumoniae & 28.5 & 0.7 & 14.1 & 0.0 & 4.1 & 0.0 \\
\hline \multirow[t]{2}{*}{ Surface sterilized } & 5.5 & 4.9 & 3.8 & 3.8 & 7.5 & 0.0 \\
\hline & \multicolumn{6}{|c|}{ (P>F) - - } \\
\hline Grass species & \multirow{2}{*}{\multicolumn{2}{|c|}{$\begin{array}{l}0.10 \\
0.05\end{array}$}} & \multicolumn{2}{|c|}{0.05} & \multirow{2}{*}{\multicolumn{2}{|c|}{$\begin{array}{c}\text { NS } \\
0.05\end{array}$}} \\
\hline Bacteria & & & & & & \\
\hline $\mathrm{CV}(\%)$ & \multicolumn{2}{|c|}{160} & \multicolumn{2}{|c|}{138} & \multicolumn{2}{|c|}{191} \\
\hline
\end{tabular}

Table 3. Bacterial species composition and colony forming units (cfu) isolated from eastern gamagrass roots collected 22 June 1992 from 3 north Missouri locations.

\begin{tabular}{lccc}
\hline & & & \multicolumn{2}{c}{$\begin{array}{c}\text { Clifton } \\
\text { Hill }\end{array}$} \\
\hline & Columbia & Elsberry & Hacterial species \\
Fluorescent pseudomonads 1 & 6.0 & 8.3 & 2.9 \\
Pseudomonas cepacia & 6.1 & 5.1 & 1.0 \\
Xanthomonas maltophilia & 2.1 & 2.4 & 1.0 \\
Rhodococcus spp. & 1.1 & 2.9 & 0.2 \\
Agrobacterium spp. & 2.3 & 0.5 & 0.5 \\
Bacillus spp. & 0.6 & 0.5 & 0.0 \\
\hline
\end{tabular}

${ }^{1}$ Fluorescent pseudomonads include $P$. fluorescens, $P$. aeruginosa and $P$. putida.

Table 4. Percentage of incubation tubes showing nitrogenase activity which contained selected bacterial species. Incubation tubes sampled contained eastern gamagrass roots collected 22 June 1992 from 3 north Missouri locations.

\begin{tabular}{lccc}
\hline \hline Bacterial species & Columbia & Elsberry & $\begin{array}{c}\text { Clifton } \\
\text { Hill }\end{array}$ \\
\hline & $-1-\ldots-1 \%)$ & 15.0 \\
Fluorescent pseudomonads ${ }^{1}$ & 12.5 & 11.8 & 10.0 \\
Pseudomonas cepacia $_{\text {Xanthomonas maltophilia }}$ & 25.0 & 29.4 & 55.0 \\
Rhodococcus spp. & 38.1 & 47.1 & 0.0 \\
Agrobacterium spp. & 12.5 & 0.0 & 10.0 \\
Flavobacterium spp. & 12.5 & 0.0 & 5.0 \\
Azospirillum braziliense & 0.0 & 0.0 & 0.0 \\
Number of tubes with activity & 0.0 & 5.9 & 20 \\
\hline
\end{tabular}

'Fluorescent pseudomonads include $P$. fluorescens, $P$. aeruginosa and $P$. putida.

Azospirillum braziliense was isolated from $6 \%$ of the tubes showing activity from the Elsberry site. Flavobacterium spp. was isolated from $5 \%$ of the tubes showing nitrogenase activity at the Clifton Hill site.

Our results suggest that eastern gamagrass is capable of associative $\mathrm{N}$-fixation, and the degree of nitrogenase activity measured in eastern gamagrass was greater than measured in switchgrass. It is not possible to quantify rates of $\mathrm{N}$ that may be fixed in the field using this technique because the preincubation period in the excised root assay leads to abnormal proliferation of anaerobic and microaerophilic $\mathrm{N}$-fixing organisms and therefore produces artificially high estimates of nitrogenase activity in grass rhizospheres (Eskew and Ting 1977, Okon et al. 1977). Most estimates using in situ measurements suggest $<10 \mathrm{~kg} \mathrm{~N} \mathrm{ha}^{-1}$ year $^{-1}$ are fixed by this mechanism, although $76 \mathrm{~kg} \mathrm{~N} \mathrm{ha}{ }^{-1}$ was estimated for Paspalum urvillei growing in low-lying, seasonally waterlogged areas in Zimbabwe (Maasdorf 1987). Quantities of $\mathbf{N}$ fixed by associative $\mathrm{N}$-fixation may be small when compared to other sources of $\mathbf{N}$ inputs such as symbiotic $\mathbf{N}$-fixation by legumes and atmospheric inputs. However, low annual inputs by associative $\mathrm{N}$-fixation could have contributed appreciable amounts of $\mathrm{N}$ to prairie soils over time.

This is the first report of associative $\mathrm{N}$-fixation in eastern gamagrass. Isolation of the well-known N-fixer Azospirillum braziliense suggests that eastern gamagrass stands provide conditions suitable for associative $\mathrm{N}$-fixation. The role of associative $\mathrm{N}$-fixation in contributing to the $\mathbf{N}$ cycle of prairie ecosystems and the potential to improve eastern gamagrass productivity through identification and selection of compatible and efficient diazotrophs should stimulate further investigation of $\mathrm{N}$-fixing associations with warmseason grasses.

\section{Literature Cited}

Albrecht, S.L., Y. Okon, J. Lonnquist, and R.H. Burris. 1981. Nitrogen fixation by corn-Azospirillum associations in a temperate climate. Crop Sci. 21:301-306.

Anderson, R.C., and A.E. Liberta. 1986. Occurrence of fungal-inhibiting Pseudomonas on caryopses of Tripsacum dactyloides $\mathrm{L}$. and its implication for seed survival and agriculture application. J. Appl. Bacteriol. 61:195-199.

Barber, L.E., J.D. Tjepkema, S.A. Russell, and H.J. Evans. 1976. Acetylene reduction (nitrogen fixation) associated with corn inoculated with Spirillum. Appl. Environ. Microbiol. 32:108 113.

Barraquio, W.L., J.K. Ladha, and I. Watanabe. 1983. Isolation and identification of $\mathrm{N}_{2}$-fixing Pseudomonas associated with wetland rice. Can. J. Microbiol. 29:867-873.

Eskew, D.L., and I.P. Ting. 1977. Comparison of intact plant and excised root assays for acetylene reduction in grass rhizospheres. Plant Sci Letters 8:327-331.

Gomez, K.A., and A.A. Gomez. 1984. Statistical procedures for agricultural research. John Wiley and Sons, N.Y..

Hitchcock, A.S., and A. Chase. 1971. Manual of the grasses of the United States (2nd ed.). Dover Publ., N.Y.

Jayaswal, R.K., M.A. Fernandez, and R.G. Schroeder. 1990. Isolation and characterization of a Pseudomonas strain that restricts growth of various phytopathogenic fungi. Appl. Environ. Microbiol. 56:1053-1058.

Klucas, R.V. 1991. Associative nitrogen fixation in plants, p. 187-198. In: M. Dilworth and A. Glenn (eds.) Biology and biochemistry of nitrogen fixation. Elsevier Science Publ. B.V., Amsterdam.

Klucas, R.V. and W. Pedersen. 1980. Nitrogen fixation associated with roots of sorghum and wheat, p. 243-255. In: W.E. Newman and W.H Orme-Johnson (eds.) Nitrogen fixation, Vol. II. University Park Press, Baltimore, Md.

Lifshitz, R., J.W. Kloepper, F.M. Scher, E.M. Tipping, and M. Laliberte. 1986. Nitrogen-fixing Pseudomonads isolated from roots of plants grown in the Canadian high arctic. Appl. Environ. Microbiol. 51:251-255.

Maasdorf, B.V. 1987. Contribution of associative $\mathrm{N}_{2}$-fixation (acetylene reduction) in some grassland ecosystems in Zimbabwe. Soil Biol. Biochem. 19:7-12. 
Morris, D.R., D.A. Zuberer, and R.W. Weaver. 1985. Nitrogen fixation by intact grass-soil cores using ${ }^{15} \mathrm{~N}$ and acetylene reduction. Soil Biol. Biochem. 17:87-91.

Neyra, C.A., and J. Dobereiner. 1977. Nitrogen fixation in grasses. Adv. Agron. 29:1-38.

Okon, Y., S.L. Albrecht, and R.H. Burris. 1977. Methods for growing Spirillum lipoferum and for counting it in pure culture and in association with plants. Appl. Environ. Microbiol. 33:85-88.

Pedersen, W.L., K. Chakrabarty, R.V. Klucas, and A.K. Vidaver. 1978. Nitrogen fixation (acetylene reduction) associated with roots of winter wheat and sorghum in Nebraska. Appl. Environ. Microbiol. 35:129-135.
Sasser, M. 1990. Identification of bacteria through fatty acid analysis, p. 199-204. In: Z. Klement, K. Rudolph, and D.C. Sands (eds.), Methods in phytobacteriology. Akademiai Kiado, Budapest.

Tjepkema, J.D. 1975. Nitrogenase activity in the rhizosphere of Panicum virgatum. Soil Biol. Biochem. 7:179-180.

Tjepkema, J.D., and R.H. Burris. 1976. Nitrogenase activity associated with some Wisconsin prairie grasses. Plant Soil 45:81-94.

\section{$J R M$ 46:378-382}

\section{Richard Hart}

The sentence on page 379 under Methods, which now reads "About $90 \%$ of scientific papers are never cited at all (Garfield 1983)", should have read "About $90 \%$ of scientific papers are cited one or more times; about $10 \%$ are never cited at all (Garfield 1976)." The citation is:

Garfield, E. 1976. Is the ratio between number of citations and publications cited a true constant? Curr. Cont. Agr. Biol. Environ. Sci. 7(6):5-7.

I received a note from Eugene Garfield pointing out the error in the above sentence, and also questioning my statement that economists rarely cite the key papers in stocking rate research. He suggested that I should look in the Social Sciences Citation Index for such citations. I checked that Index for the last 5 years and found only 3 citations in addition to the 2 found in the Science Citation Index. Two of the papers cited Noy-Meir (1975) and one cited Mott (1960). Therefore the statement still holds; economists rarely cite the key papers in stocking rate research.

Finally, I stated that Jones and Sandland and I proposed similar paradigms, but neither of their key papers proposed a constant gain at low sotcking rates. Raymond Jones sent me a 1981 paper in which he proposes such a gain plateau at low stocking rates. The citation is:

Jones, R.J. 1981. Interpreting fixed stocking rate experiments. p. 419-431 In J.L. Wheeler and R.D. Mochrie (eds.) Forage evaluation: concepts and techniques. CSIRO, East Melbourne, Victoria, Australia and AFGC, Lexington, KY.

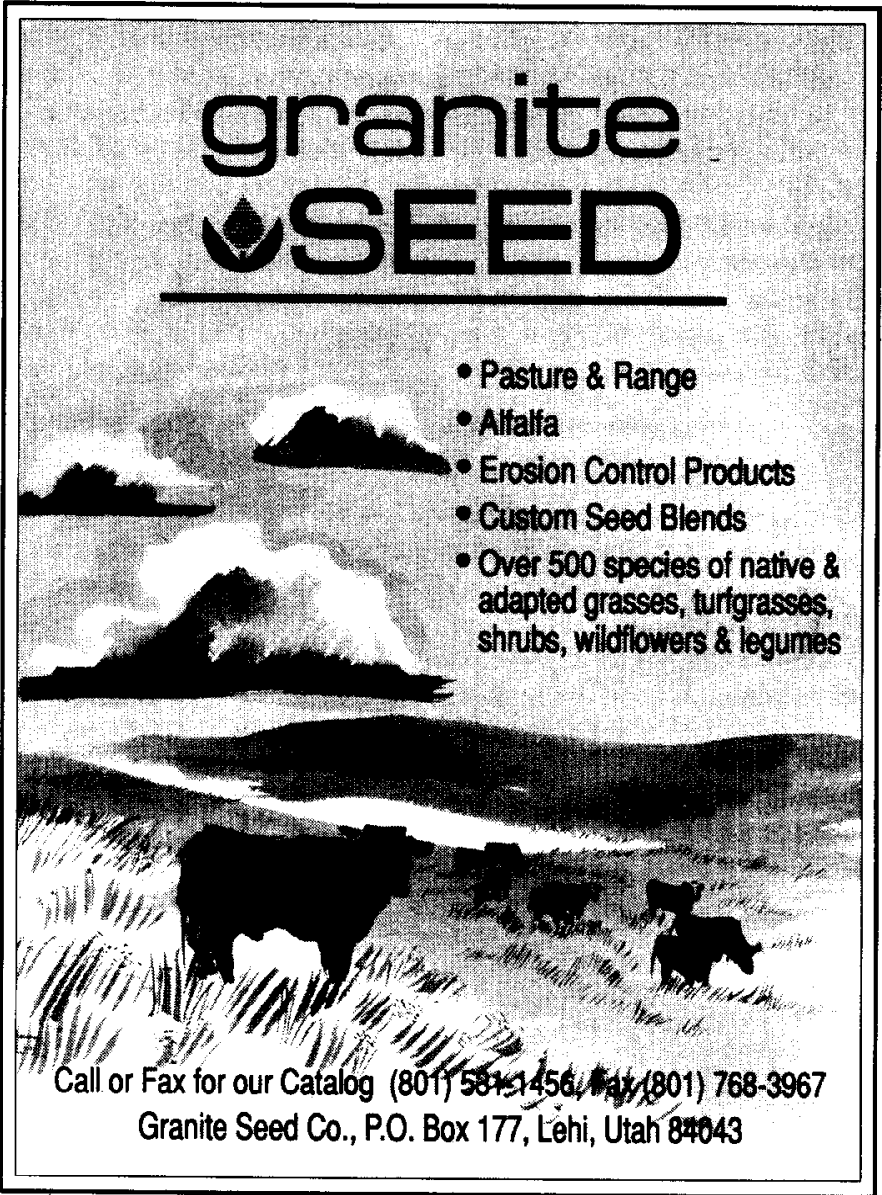

